\title{
The Red Line: Creating a Museum of the Chinese Revolution*
}

\section{Chang-tai Hung}

\begin{abstract}
The establishment of the Museum of the Chinese Revolution, which opened its doors in Beijing's Tiananmen Square on 1 July 1961, the 40th anniversary of the founding of the Chinese Communist Party, was a complicated political and cultural decision on the part of the Chinese government. The museum was never intended to be an artistic enterprise. Rather, it was conceived as a political institution to serve the interest of the Party. This article argues that the Party was ubiquitous in the building of the museum, exercising tight control through strict institutional means, especially through its Propaganda Department. Museum staff, under the close supervision of senior Party officials, sought to pursue an indigenous path different from the Soviet model. Staff members collected artifacts related to the Chinese Communist Revolution, commissioned historical paintings, arranged displays according to the historical framework stipulated by Mao Zedong, and, most important, struggled to instil in the museum the correct "Red Line," that is, the policy of the CCP under Mao's leadership. The article concludes that the museum was an intricate amalgam of political supervision from the top, official historical interpretations, strategic displays and a reflection of the internal Party struggle. The construction of the museum reflects the attempt by the CCP to control the collective memory of the nation and to monopolize the writing of history.
\end{abstract}

Wang Yeqiu (1909-87), a literary historian and devoted Communist, was jubilant when, on 31 January 1949 after a two-month campaign of military encirclement, communist troops finally occupied Kuomintangruled Beiping (renamed Beijing in October 1949, its name prior to 1928). Wang was concerned, however, that the Kuomintang (Nationalists) would destroy much of the trappings of the Chinese Communist Party (CCP) as they retreated. He was particularly anxious that an important historical artifact would be lost: the scaffold used by warlord Zhang Zuolin (1875-1928) to execute by hanging Li Dazhao (1899-1927), co-founder of the CCP. "The scaffold was uppermost in my mind when I entered Beiping. I was determined to recover it despite all obstacles," he said. "If found," he added, "it will be displayed in a future museum of the revolution so that viewers may know about the heroic death of Comrade Li Dazhao - one of the founders of our Party." To his great relief, Wang ultimately tracked down the scaffold in the Kuomintang's No. 2 Prison outside Deshengmen Gate. ${ }^{1}$ And, indeed, it became the first item collected by the future Museum of the Chinese Revolution (Zhongguo

* Research for this article was generously funded by a grant from the Research Grants Council, Hong Kong.

1. Guojia wenwuju (ed.), Huiyi Wang Yeqiu (Remembering Wang Yeqiu) (Beijing: Wenwu chubanshe, 1995), pp. 37-38, 140.

(C) The China Quarterly, 2005 
geming bowuguan), which would open its doors in Tiananmen Square on 1 July 1961, the 40th anniversary of the founding of the CCP.

Wang's recovery of Li Dazhao's scaffold was part of a large, concerted effort mounted by communist officials, with the enthusiastic support of intellectuals such as Wang, to create a museum honouring the communist martyrs and, more important, chronicling the gruelling but, in their view, assured path of the CCP's final victory in 1949. But Wang's determination to collect communist artifacts raises complicated questions regarding the exact nature of a museum in Communist China. How might a museum present the history of modern China in general, and the history of the Chinese Communist Party in particular? If creating a museum was largely an ideological undertaking, what sorts of artifacts should it include? What images did the Communists intend to convey through the museum's displays, and by what means?

The study of museums has emerged as a new field in cultural history. Recent works on the memorial space of Tiananmen Square as well as the paintings and modernity of Chinese museums have shed new light on the history of memory and the exhibitory culture in modern China. ${ }^{2}$ But few scholars have delved into the background or explored the institutional environment surrounding the establishment of political museums in the early years of the People's Republic of China (PRC). This article attempts to fill this void by focusing on the creation of the Museum of the Chinese Revolution and evaluating the museum's political implications. I argue that a Chinese revolutionary museum was constructed for two purposes: to legitimize the CCP's rule by carefully re-creating, through exhibitions, a desirable image of the Party with which to impress the public, and to highlight the pivotal role played by Mao Zedong (1893-1967) in guiding the Party to its final victory. But although the exhibits were to be under the exclusive control of the Party, there was a long and difficult journey before an acceptable format was finally reached. There were years of debates and compromises, with the participation of many different departments, both of the Party and of the government, and myriad Party officials; all this at a time of frenzied economic change (including the Great Leap Forward) and deteriorating relations between China and the Soviet Union in the late 1950s.

\section{Early History}

The idea of building a museum to document the history of the CCP and to house its artifacts and artwork was first raised in 1933 during the Jiangxi Soviet period (1931-34), and perhaps even earlier. ${ }^{3}$ But the plan

2. Wu Hung, "Tiananmen Square: a political history of monuments," Representations, No. 35 (Summer 1991), pp. 84-117; Kirk A. Denton, "Visual memory and the construction of a revolutionary past: paintings from the Museum of the Chinese Revolution," Modern Chinese Literature and Culture, Vol. 12, No. 2 (Fall 2000), pp. 203-235; Qin Shao, "Exhibiting the modern: the creation of the first Chinese museum, 1905-1930," The China Quarterly, No. 179 (September 2004), pp. 684-702.

3. Zhongguo geming bowuguan (ed.), Jiefanqu zhanlanhui ziliao (Materials on Exhibition in the Liberated Areas) (Beijing: Wenwu chubanshe, 1988), p. 5. 
never materialized because of the military and social uncertainties at the time. A similar notion was reiterated during the Yan'an era (1937-47) when, in 1946, the Party established a Preparatory Committee for the Shaan-Gan-Ning Border Region Museum of the Revolution to formulate a concrete plan, but the ideas were never enacted. Once again, the escalating tensions between the Communists and the Nationalists interrupted preparations. ${ }^{4}$ The concept did not receive formal attention again until after the establishment of the PRC in 1949.

Immediately after Beiping was "liberated" in January 1949, the CCP established the Committee to Control Cultural Affairs which acted swiftly to place universities, media, and cultural institutions such as museums and libraries under Party control, among them the Palace Museum and the Beiping Historical Museum, the two major museums in Beijing. Wang Yeqiu was in charge of redefining the missions of the museums and planning their future. ${ }^{5}$ In May 1950 the State Council issued an order forbidding any smuggling of "precious cultural relics" out of the country, including architectural structures, paintings, sculpture and rare books. ${ }^{6}$

The new government's policies bore a close resemblance to those of the Soviets. After the Bolsheviks seized power in 1917, they moved swiftly to nationalize the tsar's palaces and all works of art, and to set up a special Board for Museums and the Protection of Art Monuments and Antiques to protect cultural relics. In September 1918 the new Soviet government issued a decree forbidding the sale of valuable cultural and artistic objects to foreign countries. ${ }^{7}$ The Chinese undertaking, however, was more elaborate, better co-ordinated and more tightly controlled.

In May 1949 the Committee to Control Cultural Affairs issued an announcement, through the office of the Beiping Historical Museum, to collect revolutionary documents and artifacts. It focused on two areas: first, all documents related to the Communist Party's clandestine or openly published newspapers, pictorials, proclamations, slogans, photographs and woodcuts; and secondly, artifacts such as the relics of communist martyrs, flags, official seals and stamps. ${ }^{8}$ This was the first step towards the eventual establishment of a museum of the Chinese revolution.

The tempo to assemble memorable artifacts was hastened when a new Cultural Relics Bureau (Wenwuju) was established within the new Ministry of Culture in late 1949 to oversee the entire construction plan for the museum and to improve the co-ordination of resources. The renowned cultural historian Zheng Zhenduo (1898-1958) was appointed its first director, with Wang Yeqiu as his deputy, responsible for the bureau's daily operations. The new bureau also launched a journal entitled Wenwu

\footnotetext{
4. Ibid.

5. Remembering Wang Yeqiu, pp. 58-95.

6. Wenwu cankao ziliao (Reference Materials on Cultural Relics), No. 1-6 (October 1950), pp. 5-8.

7. Albina Danilova, Dedicated to the Muses (Moscow: Novosti, 1990), pp. 16-17.

8. Renmin ribao (People's Daily), 4 May 1949.
} 
cankao ziliao (Reference Materials on Cultural Relics), later renamed Wenwu (Cultural Relics).

The Communists were planning a museum of an entirely different nature from museums of the past. After the founding of the PRC in October 1949, the Ministry of Culture took control of 21 major museums. Wang Yeqiu was critical of these old-style museums, dividing them into two types: those founded by "foreign imperialists," which bore a clear imprint of aggression, and "antique display places" founded by native Chinese. ${ }^{9}$ In Wang's view they were products of a bygone era, ill suited to the needs of a modern socialist society. In March 1950 a Preparatory Committee for the National Museum of the Revolution was formed. It was renamed the Preparatory Committee for the Central Museum of the Revolution (PCCMR) in July 1950. This was the first time since the establishment of the PRC that the term "museum of the revolution" was officially used. ${ }^{10}$

\section{The Soviet Influence}

How does one build a museum of the revolution? Which model and guidelines should one follow? No one involved, including Zheng Zhenduo and Wang Yeqiu, were trained museologists. They were amateurs venturing into new territory. As the new PRC government adopted an increasingly anti-imperialist and anti-American policy, it looked to the friendly socialist Soviet Union for assistance. The famous saying of Mao Zedong, "leaning to one side," was an apt summation of the overall pro-Soviet policy and sentiment. ${ }^{11}$

The opportunity for the planners of the Chinese museum to observe Soviet museums first hand came in the autumn of 1950 when Wang Yeqiu, as head of a Chinese delegation, went to Moscow to stage a large-scale exhibition of more than 1,000 Chinese works of art at the renowned Tretyakov Gallery. ${ }^{12}$ Wang found the trip exhilarating. Not only was he greeted by Aleksandr Gerasimov, president of the USSR Academy of Arts and one of the most influential figures in Soviet art circles, he was also invited to visit a number of major museums in Moscow, including the National Museum of the Revolution on Gorky Street (now Tverskaya Ulitsa). The rich collections he saw there left him awestruck. $^{13}$

For Wang, the displays at the National Museum of the Revolution chronicled the glorious path of the history of the Bolshevik revolution. Lenin's central role was naturally highlighted and his artifacts prominently exhibited, including such influential publications as the first edition

9. Remembering Wang Yeqiu, pp. 44-45.

10. Wenwu cankao ziliao, No. 1-6 (October 1950), pp. 33-35.

11. Mao Zedong, "On the people's democratic dictatorship," in Mao Zedong, Selected Works of Mao Tse-tung, 5 vols. (Peking: Foreign Languages Press, 1967-1977), Vol. 4, p. 415.

12. Wang Yeqiu, "Fang Su guangan" ("Impressions of a visit to the Soviet Union"), Wenwu cankao ziliao, No. 11 (November 1950), pp. 118-19.

13. Ibid. pp. 115-125. 
of What Is To Be Done? The museum also extensively covered Stalin. The Bolshevik revolution was divided chronologically into four periods, with the October Revolution serving as the defining event: the first stage explored Russian society before the October Revolution; the second, the prelude to the revolution; the third, the revolution itself; and the fourth, the construction of socialism following the revolution. ${ }^{14}$ Wang also noted that the Soviet museums were part of a larger design of proletarian education, an essential element of a careful plan to enlighten the masses and disseminate socialist information. Soviet museums, in his words, "are inextricably linked with the people, serving as their classroom." 15

Wang's visit was the first of many study trips by Chinese pilgrims to the Soviet capital as cultural exchanges between the PRC and the Soviet Union increased. In an article on the Soviet museums, the historian Jian Bozan (1898-1968) classified them into three categories: comprehensive, which included the State History Museum; specialized, which included the Museum of Ethnography; and memorial, which included the Central Lenin Museum and the Gorky Museum. It was the memorial museums, Jian observed, that were predominant after the Bolshevik revolution, as the new government honoured the heroes and martyrs who distinguished themselves. $^{16}$

To gain a better look into the Soviet museum system, Russian museologists were invited to China to deliver lectures and to hold discussions with the Chinese. ${ }^{17}$ Reference Materials on Cultural Relics devoted ample pages to the introduction of Soviet museums, and Russian books on museology were also translated into Chinese. One example is Osnovy Sovetskogo muzeevedeniia (Principles of Soviet Museum Management) (1955), a detailed survey of the methods of running a museum couched in familiar Marxist rhetoric. ${ }^{18}$

Clearly it was the history of the Bolshevik revolution that preoccupied the minds of Chinese visitors, and, as a result, the Museum of the Revolution, the Central Lenin Museum and the Red Army Museum attracted the most attention. They found Lenin museums to be ubiquitous in the Soviet Union, turning up in Leningrad, Kiev and Tbilisi. ${ }^{19}$ These were a paean to the architect of the Bolshevik revolution and became a popular site for people to visit. ${ }^{20}$ Memorial museums dedicated to individual communist heroes and martyrs also attracted the Chinese, such as the Nikolai Ostrovsky Museum on Gorky Street in Moscow. Ostrovsky was a socialist-realist writer whose novel, How the Steel Was Tempered (1932-34), a tale about a Komsomol member, Pavel Korchagin, who

14. Wang Yeqiu, "Sulian guoli geming bowuguan" ("The Soviet National Museum of the Revolution”), Wenwu cankao ziliao, No. 10 (October 1950), pp. 66-77.

15. Wang Yeqiu, "Fang Su guangan," p. 120.

16. Jian Bozan, "Canguan Sulian bowuguan de yinxiang" ("Impressions upon visiting Soviet museums”), Wenwu cankao ziliao, No. 4 (May 1953), pp. 30-31.

17. Ibid. p. 43.

18. Translated into Chinese as Sulian bowuguanxue jichu (Beijing: Wenwu chubanshe, 1957).

19. Renmin ribao, 25 April 1950.

20. Jian Bozan, "Impressions upon visiting Soviet museums," p. 40 
dedicates his life entirely to the communist cause, had been translated into Chinese in the 1940s and became extremely popular among leftist youth. In his visit to this museum, Wang praised Ostrovsky as a writer "who used art and literature to serve the people.",21

\section{Building a Museum of the Chinese Revolution}

The idea that the primary goal of a public museum is to educate and enlighten morally and socially dates back to the opening of the Louvre in Paris in 1793. There is a famous saying by Jacques-Louis David that the French museum should not be "a vain assemblage of frivolous luxury objects that serve only to satisfy idle curiosity" but rather should serve as "an imposing school." 22 The Louvre, which Carol Duncan and Alan Wallach labelled a "universal survey museum," was restricted at the start to royal visitors but was later transformed into an institution accessible to all. Designed to reflect a novel set of social relations, the museum's artwork was grouped by national schools and art-historical periods in the service of a democratic citizenry. Its visitors were considered "shareholders" of the state. ${ }^{23}$ In contrast, the Soviet museums in Moscow embraced an entirely different goal. In the words of Boris Groys, the specific philosophy of Soviet museums was to forge "a single, total visual space within which to efface the boundary separating art from life" and, in so doing, devote itself to the service of the Stalinist ideology. ${ }^{24}$

Although Wang Yeqiu was extremely impressed by the Soviet museums, particularly that their basic foundation rested on two distinct themes - the success of the October Revolution and the pivotal role played by Lenin and his close associates ${ }^{25}$ - he nevertheless remained determined to build a museum in China that would be distinctly Chinese. This future museum would serve as a place both to preserve and to reconstruct an indigenous political memory. Wang insisted that a future Chinese revolutionary museum would be unique in its dissemination not only of Marxism but also of "the thought of Mao Zedong.",26

In February 1950 the Cultural Relics Bureau issued a second, more detailed notice announcing a nationwide collection campaign. Drafted by Wang Yeqiu, this statement spelled out for the first time the period that interested the bureau: the collection should closely follow the development of modern Chinese history, encompassing the time since the Opium War (1839-42), but should centre on "the period of the New Democratic

21. Wenwu cankao ziliao, No. 10 (October 1950), p. 79

22. Andrew McClellan, Inventing the Louvre: Art, Politics, and the Origins of the Modern Museum in Eighteenth-Century Paris (Berkeley: University of California Press, 1994), p. 91.

23. Carol Duncan and Alan Wallach, "The universal survey museum," Art History, Vol. 3, No. 4 (December 1980), p. 456.

24. Boris Groys, "The struggle against the museums; or, the display of art in totalitarian space," in Daniel J. Sherman and Irit Rogoff (eds.), Museum Culture: Histories, Discourses, Spectacles (Minneapolis: University of Minnesota Press, 1994), p. 144.

25. Wang Yeqiu, "The Soviet National Museum of the Revolution," p. 66.

26. Remembering Wang Yeqiu, p. 48. 
Revolution after the May Fourth Movement when the CCP assumed the nation's leadership role." 27

The success of the campaign to build the museum may be seen in the assemblage of more than 1,300 items by the end of $1950 .{ }^{28}$ One was the cutting knife used by warlord soldiers in 1947, in Shanxi, to execute Liu Hulan (1932-47), a young girl whom Mao Zedong personally eulogized as a martyr. Other cherished pieces included the government bonds issued by the Jiangxi Soviet. ${ }^{29}$

Revolutionary artifacts were not the only items collected by the museum organizers. They also created visual representations in order to produce a specific view of recent Chinese history, especially regarding the development of the Party. This was most evident when certain artists were commissioned to recapture critical moments in the history of the CCP. Three oil paintings were notable examples: The Founding of the Nation (Kaiguo dadian; 1952-53) by Dong Xiwen (1914-73), and Tunnel Warfare (Didaozhan; 1951) and The Rectification Report (Zhengfeng baogao; 1951) by Luo Gongliu (1916-2004). ${ }^{30}$ Dong's painting, which became a celebrated propaganda piece, portrays Mao's official proclamation of the founding of the PRC in October 1949 atop Tiananmen Gate. The painting vividly captures the triumphant finale of the CCP's struggle as well as the beginning of a promising future under communism. Such commissioned works are common, of course, in museum history, as seen in Aleksandr Gerasimov's Lenin at the Tribune (1930), a grand tribute to the Bolshevik leader, and Mikhail Khmelko's Triumph of Our Fatherland (1949), a celebration of the defeat of Nazi Germany on Red Square.

Essential to the creation of a museum of the revolution was to find a new home for it. Wang Yeqiu knew without question that the current office of the PCCMR, which occupied just three rooms in a dilapidated building in the western part of the old palace, was clearly inadequate. His idea to relocate the museum received strong support from high Party officials such as Dong Biwu (1886-1975) and Lu Dingyi (1906-96). ${ }^{31}$

The first proposal to build the new museum in Tiananmen Square was made by Beijing's Capital Planning Committee (founded in 1949) in early $1953 .{ }^{32}$ Locating the museum in the capital's symbolic centre, Wang and his associates believed, would surely affirm its centrality and increase its visibility among the Chinese people. But the government took no further action until August 1958, when, at a meeting of the CCP Politburo in Beidaihe, the decision was made to build, by 1 October 1959, ten monumental buildings to celebrate the tenth anniversary of the PRC's

27. Renmin ribao, 13 February 1950.

28. Remembering Wang Yeqiu, p. 151.

29. Renmin ribao, 21 February 1950.

30. Geming bowuguan gongzuo yanjiu (Journal of the Museum of the Chinese Revolution), No. 1 (1984), p. 11. Interview with Luo Gongliu, 16 January 2004, Beijing. See also Denton, "Visual memory."

31. Remembering Wang Yeqiu, pp. 144-45.

32. Ibid. p. 149. 
founding. These were to include the Great Hall of the People, the Museum of the Chinese Revolution and the Chinese Military Museum. A Preparatory Committee on the Construction of the Museum of the Chinese Revolution and the Museum of Chinese History was formed, headed by Qian Junrui (1908-85), the vice-minister of culture, with Wang Yeqiu as the managing director. ${ }^{33}$

Construction of the museum began on 28 October 1958 and by 31 August 1959, one year after the decision at the Beidaihe meeting, the structure was completed. Such amazing speed - the Communists called it "a miracle" - was clearly politically motivated in order to meet the October deadline, making it possible for the building to be presented as a National Day "gift" to the nation, as the communist publications described it. ${ }^{34}$ The building complex, located at the eastern end of Tiananmen Square, houses two museums: in the north wing is the Museum of the Chinese Revolution and at the south wing is the Museum of Chinese History. The architect responsible for the design was Zhang Kaiji (b. 1912), who was trained at Nanjing's Central University. ${ }^{35}$

The museum complex is a massive, rectangular-shaped edifice. It occupies 65,152 square metres of floor space, and covers 313 metres from north to south and 149 metres from east to west (see Figure 1). The complex faces the Great Hall of the People, another imposing building at the opposite end of Tiananmen Square, where major national meetings are held. The front entrance of the compound boasts two rows of giant columns, 12 in each row. The top of the entrance, in the centre, is decorated with a giant five-pointed star encircled by ears of wheat, a common communist symbol of a bumper harvest. Flanking the star are 16 red flags, eight each side, which represent the supremacy of the CCP and the triumph of the revolution. The square-shaped columns were designed to form a perfect balance with the round columns of the Great Hall of the People, an idea that Premier Zhou Enlai (1898-1976) allegedly suggested. ${ }^{36}$ Guarding the two sides of the entrance are two pylons. They rise 40 metres at the highest point of the building and are in the shape of a burning torch, signifying Mao's famous 1930 saying, "a single spark can start a prairie fire," intended to exude confidence about the inevitability of a communist victory in China. The eaves, which are designed with a combination of traditional green and yellow glazed tiles, project another distinct Chinese image. Statues of communist giants - Marx, Engels, Lenin, and Stalin - stand in the centre of the great hall. The walls are also

33. "Guanyu Geming, Lishi liang bowuguan choujian qingkuang de baogao" ("A report on the preparation for the construction of the Museum of the Chinese Revolution and the Museum of Chinese History") (1959), Beijing Municipal Archives, 164-1-32.

34. Zhongguo geming bowuguan wushinian bianweihui (ed.), Zhongguo geming bowuguan wushinian (The 50 Years of the Museum of the Chinese Revolution) (Shenzhen: Haitian chubanshe, 2001), p. 11.

35. Zhang Kaiji, "Canjia guoqing gongcheng sheji de diandi huiyi" ("Reminiscences of my participation in the National Day projects"), Beijing wenshi ziliao (Historical Materials on Beijing), No. 49 (1994), p. 40.

36. Ibid. p. 33; Interview with Zhang Kaiji, 16 September 1996, Beijing. 
Figure 1: The Museum of the Chinese Revolution (on the left side) (author's photo, 2002)

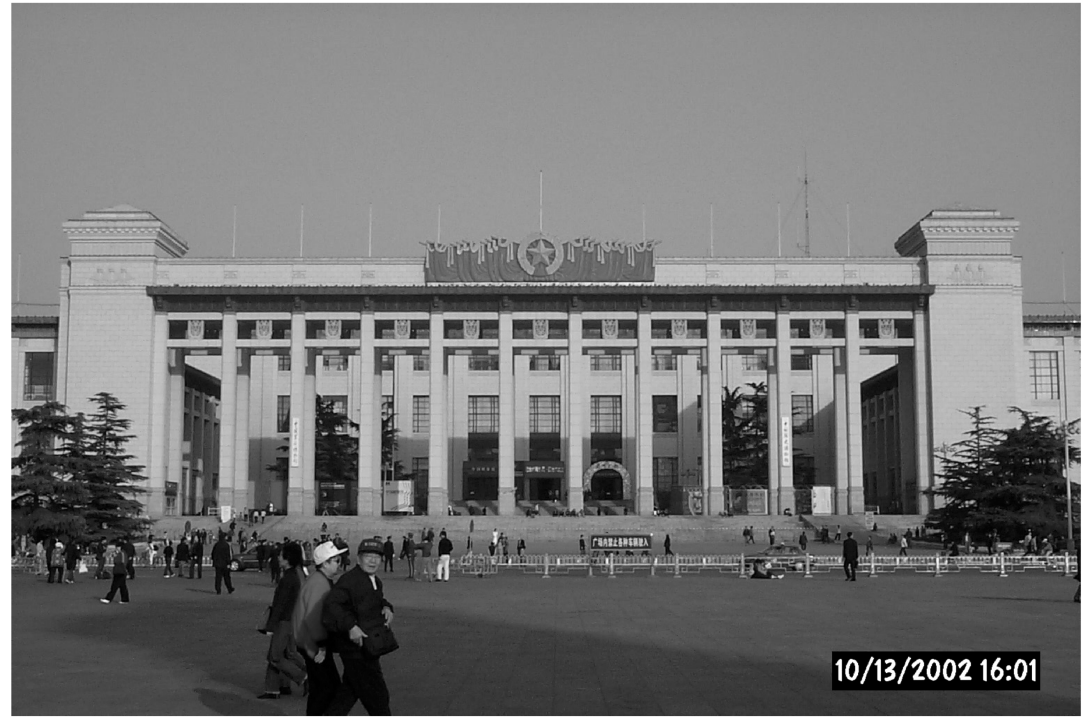

decorated with the familiar design of white doves, symbolizing peace and international friendship.

The museum exudes a strong sense of nationalism. Zhang Kaiji proudly stated that it was based entirely on Chinese design and construction, without assistance from any foreign countries, including the Soviet Union. The "miraculous construction," in his words, "is owed primarily to the leadership of the Party with the assistance of the entire nation." ${ }^{37}$ By the late 1950s the relationship between China and the Soviet Union had become strained to the point that any Soviet assistance would have been deemed politically incorrect and humiliating. Thus Zhang's declaration highlighted nationalistic pride along the official Party line and reflected the political climate at the time. China was engulfed by then in the frantic and chaotic Great Leap Forward, which rhetorically stressed the principle of self-reliance, an ideal embodied in the museum. ${ }^{38}$

\section{The CCP Propaganda Department}

From the initial planning stage in the early 1950s to the eventual opening of the Museum of the Chinese Revolution in 1961, the CCP was clearly in full control of both the structure and contents of the museum. Which objects to display was a major concern of Party officials, for at the

37. Jianzhu xuebao (Architectural Journal), No. 9-10 (1959), p. 33.

38. "Zhongguo geming, lishi bowuguan gongcheng jiben zongjie" ("A summary of the construction work of the Museum of the Chinese Revolution and the Museum of Chinese History”) (1959), Beijing Municipal Archives, 47-1-90. 
heart of the museum was the effort to portray the proper image of the Party that would proclaim to the public the Communists' claim to power and legitimacy.

Since the second half of the 19th century the sphere of culture, in both Europe and America, had fallen increasingly under governmental control. However, state involvement in museums and art galleries in those countries was, for the most part, indirectly exercised via boards of trustees, leaving room for institutions to make autonomous decisions. ${ }^{39}$ This was not so in socialist China, where the Party was ubiquitous in the monitoring of cultural policies and in exercising tight control by means of strict institutional measures. In the case of the Museum of the Chinese Revolution, the Party made its presence known both through the Propaganda Department of the CCP Central Committee (Zhonggong zhongyang xuanchuanbu) and through the many Party committees that had been set up to oversee the museum's construction.

Institutionally museums were placed under the jurisdiction of the Ministry of Culture. But, in reality, that ministry played only a subordinate role to the more powerful Propaganda Department. A Leninist party, the CCP firmly believed in tight organization, efficiency and discipline, and thus the Propaganda Department's control of the nation's cultural and literary activities, as well as setting their agendas, went unquestioned. Deciding on how to present the history of the CCP to the public, correctly and forcefully, was too critical a task to be left to anyone other than the most trusted in the Party. This clearly indicated the Party's primacy over the state in both ideological and cultural matters, visible proof of their unequal power relationship.

One of the earliest exhibitions mounted by the PCCMR was a commemoration of the 30th anniversary of the founding of the CCP - the "1 July Anniversary Exhibition" - held in July 1951 in Martial Hall (Wuyingdian) in the old imperial palace. "Before the exhibition, I remember vividly that Chen Boda [1904-89; deputy director of the Propaganda Department] arrived early to inspect the show," a former museum employee told me. ${ }^{40}$ Other key members of the department also came to inspect the exhibit, including the veteran propagandist and influential director of the department Lu Dingyi. Playing a supporting role was the Minister of Culture Shen Yanbing (Mao Dun) (1896-1981). ${ }^{41}$

The influence asserted by the Propaganda Department was to increase significantly as the building of a permanent museum progressed. Immediately after the July 1951 exhibition, which had been for internal viewing only, the CCP Central Committee issued a "Circular concerning the collection of the materials related to the Party's history," stating that the Propaganda Department would be in charge of collecting materials from

39. Nicholas M. Pearson, The State and the Visual Arts: A Discussion of State Intervention in the Visual Arts in Britain, 1760-1981 (Milton Keynes: Open University Press, 1982), p. 26.

40. Interview with museum staffer C, January 2005.

41. Beijing bowuguan xuehui zhubian (ed.), Beijing bowuguan nianjian, 1912-1987 (The Yearbook of Beijing Museums, 1912-1987) (Beijing: Beijing yanshan chubanshe, 1989), p. 197. 
inside the Party and that the Ministry of Culture would be responsible for collecting display items outside the Party. ${ }^{42}$ In April 1953 the Propaganda Department issued another directive, "An exhibition outline," specifying the rules for any future revisions of the exhibits. ${ }^{43}$

Senior Party members looked upon the Propaganda Department as the keeper of the Party's official image. For example, after reviewing a preliminary museum exhibition in 1957, Deng Xiaoping (1904-97), at the time the general secretary of the CCP Secretariat, instructed that, whenever the Ministry of Culture had completed its inspection, "the Propaganda Department must examine everything one more time," 44 a recommendation with which Premier Zhou Enlai readily concurred. ${ }^{45}$

In addition to the contributions from the Propaganda Department, the Party set up many committees to ensure the smooth progress of the entire operation. In October 1958, two months after the Beidaihe announcement, the Propaganda Department and the Ministry of Culture jointly formed "A Preparatory Task Force for the Construction of the Revolutionary Museum and the Historical Museum," with Qian Junrui as its leader and Wang Yeqiu as its bureau chief. ${ }^{46}$ To ensure the suitability of the exhibits, in September 1959 the CCP Secretariat established an even higher-level committee, the "Central Leadership Preparatory Committee of the Construction of the Museum of the Chinese Revolution." Headed by propaganda chief Lu Dingyi and Kang Sheng (1898-1975), the committee comprised such influential members as Hu Qiaomu (1912-92) and Zhou Yang (1908-89), two deputy directors of the Propaganda Department; Tian Jiaying (1922-66), Mao's secretary; and Qian Junrui. ${ }^{47}$

The direct participation of senior Party members Zhou Enlai and Deng Xiaoping in the decision-making process of the future museum, noted above, was further evidence that the Party attached great importance to the museum. As two staff members proudly pointed out: "All senior Party leaders, with the exception of Chairman Mao, Liu Shaoqi [1898-1969] and Lin Biao [1907-71], had visited the museum during its construction period." 48 Indeed, the list of top Party leaders who inspected the many rounds of possible exhibitions before the museum's official opening in 1961 comprises a veritable "Who's Who." For instance, Dong Biwu, Peng Zhen (1902-97), Nie Rongzhen (1899-1992) and Bo Yibo (b. 1908) all visited the "1 July Anniversary Exhibition" in 1951. ${ }^{49}$

Zhou Yang was a frequent visitor at the preliminary exhibits. As deputy director of the Propaganda Department and a noted Party literary

42. Ibid.

43. Ibid. pp. 197-98.

44. Fan Kongmu, "Chenlie gongzuo de lishi fazhan" "The history of the development of the exhibitions"), in Zhongguo geming bowuguan fazhan jishi (Chronicles of the Development of the Chinese Revolutionary Museum) (N.p., n.d.), p. 5.

45. Ibid.

46. The Yearbook of Beijing Museums, p. 198.

47. The 50 Years of the Museum of the Chinese Revolution, p. 140.

48. Interview with museum staffer B, January 2005 ; interview with museum staffer C.

49. Fan Kongmu, "The history of the development of the exhibitions," p. 4. 
ideologue, Zhou was the principal official responsible for the supervision of the museum exhibits. ${ }^{50}$ But for young staff members like Yu Jian, the most memorable moment came on the morning of 20 September 1959 when, several days before the scheduled opening of the new museum on the National Day of 1 October, Premier Zhou Enlai came to inspect the exhibition. ${ }^{51}$ Even though Zhou did not authorize the museum's official opening on the appointed date, having found fault with the exhibition (discussed in greater detail below), his appearance still added to the museum's prestige.

Deng Xiaoping's assessment of the exhibits on 16 May 1961 was equally significant, for he, as the general secretary of the CCP Secretariat, was responsible for giving the final approval for the opening of the Museum on 1 July. Deng arrived to examine the final preparations for the exhibition, accompanied by a large contingent of senior leaders, including such members of the Leadership Preparatory Committee as Lu Dingyi, Kang Sheng and Zhou Yang. As one museum staffer recalled years later, "Deng was happy with what he saw," and finally the opening of the museum received official endorsement. ${ }^{52}$

Despite Mao's absence from the overseers who had inspected the museum, his influence loomed large, mainly through his two secretaries, Tian Jiaying and especially $\mathrm{Hu}$ Qiaomu, who had served as his principal writer since the Yan'an days. ${ }^{53} \mathrm{Hu}$ later became the chief editor of all four volumes of Mao's Selected Works and, in 1951, authored an authoritative chronicle of the Party history, Zhongguo gongchandang de sanshi nian (Thirty Years of the Communist Party of China). ${ }^{54}$ His proximity to power brought $\mathrm{Hu}$ enormous influence. Years later Lu Dingyi complained that, as the director of the Propaganda Department, he was often overshadowed by $\mathrm{Hu}$. In Lu's words: "[Hu] Qiaomu was Chairman Mao's secretary. He often relayed the Chairman's instructions, saying that the Chairman talked about so and so. I cannot but listen to him." 55

\section{Affirming the Red Line}

The difficulty in arriving at an acceptable exhibit with which to present the history of the Party in the Museum of the Chinese Revolution is evinced by the many committees set up to oversee the construction of the museum and the repeated inspections by senior Party officials. Another

50. Yu Jian, "Zhou Yang yu bowuguan" ("Zhou Yang and museums"), Zhongguo wenwubao (Chinese Cultural Relics Press), No. 42 (October 1989), p. 2.

51. Yu Jian, "Shencha Zhongguo geming bowuguan chenlie" ("Inspecting the exhibitions of the Museum of the Chinese Revolution"), in Zhongguo renmin zhengzhi xieshang huiyi Beijingshi weiyuanhui wenshi ziliao weiyuanhui (ed.), Zhou Enlai yu Beijing (Zhou Enlai and Beijing) (Beijing: Zhongyang wenxian chubanshe, 1998), pp. 266-275.

52. Yu Jian, "Zhou Yang and museums."

53. Liu Zhonghai, Zheng Hui and Cheng Zhongyuan (eds.), Huiyi Hu Qiaomu (Remembering Hu Qiaomu) (Beijing: Dangdai Zhongguo chubanshe, 1994), p. 35.

54. Ibid. pp. 43-44, 53.

55. Chen Qingquan and Song Guangwei, Lu Dingyi zhuan (Biography of Lu Dingyi) (Beijing: Zhonggong dangshi chubanshe, 1999), p. 378. 
clear sign is the delay in the opening of the museum for almost two years (from 1 October 1959 to 1 July 1961), eleven months later than the opening of the Chinese Military Museum (Zhongguo junshi bowuguan) on 1 August $1960 .{ }^{56}$ How should the history of the CCP be represented? What exactly was the role of the Party compared to that of other parties, such as the Democratic League? Should the Nationalists, considered an opponent of the regime, be depicted at all?

It is true that the " 1 July Anniversary Exhibition" was deemed a success by Party officials, and was a much-needed strategy to legitimize the establishment of a new communist regime in China. But many in the Party thought its scope far too narrow, falling short of presenting the full and brilliant accomplishments of the Party in a broad historical and political milieu. Therefore, in January 1955 a decision was made by the Propaganda Department to extend the range of the exhibition from " 1 July anniversary" to "CCP history" in general..$^{57}$ Two years later, in September 1957, the department issued a new directive to expand the time frame even further, gradually extending the exhibition "from present CCP history to include the New Democratic Revolution, the socialist revolution and the Old Democratic Revolution." 58

Nevertheless, the question of how exactly this should be properly handled in an exhibition remained. In 1959 the CCP Central Committee spelled out six rules for the display:

- The exhibition should include the three periods mentioned above;

- The significance of historical events and individual achievements should be judged on the principle of a correct political stance and on concrete situations;

- The exhibition should be an accurate reflection of revolutionary struggles in different regions, especially those led by the CCP;

- In accordance with the principle of internationalism, assistance from the Soviet Union and other socialist countries should be demonstrated;

- The exhibit should accurately reflect the Party's nationalities policy; and

- Sizeable portraits of Party leaders may be displayed but must be limited to the members of the Politburo Standing Committee, and only the sculpture of Chairman Mao may be mounted..$^{59}$

The museum organizers agreed that the seven major events comprising the Old Democratic Revolution (1840-1919) would be included in the exhibition: the Opium War, the Taiping Rebellion, the Sino-French War, the First Sino-Japanese War of 1894, the Reform Movement of 1898, the Boxer Uprising and the Revolution of 1911. Representing the succeeding New Democratic Revolution (1919-49) would be five specific episodes: the founding of the CCP (1921), the first Revolutionary Civil War

56. Renmin ribao, 17 August 1959; Interview with museum staffer D, January 2005.

57. The Yearbook of Beijing Museums, p. 198.

58. Fan Kongmu, "The history of the development of the exhibitions," p. 5.

59. Ibid. pp. 5-6. 
(January 1924 to July 1927), the second Revolutionary Civil War (August 1927 to July 1937), the War of Resistance against the Japanese (July 1937 to August 1945), and the third Revolutionary Civil War (August 1945 to October 1949). And, finally, the socialist period (since 1949) would chronicle the unparalleled accomplishments of the new People's Republic. $^{60}$

Such a division of revolutionary history, based originally on Mao's idea of modern history contained in his influential 1940 essay "On new democracy," ${ }^{1}$ was now developed even more specifically by $\mathrm{Hu}$ Qiaomu in his Thirty Years of the Communist Party of China. ${ }^{62}$ On the surface the division seemed fairly straightforward. But in practice it was never easy, as museum staff quickly discovered. Among the three historical periods - the Old Democratic Revolution, the New Democratic Revolution and the socialist period - the second phase was of major concern. "What worried us most was the part dealing with the New Democratic Revolution," confessed Yu Jian years later. "This is contemporary history. [In this period] it is difficult to correctly treat issues related to the events inside and outside the Party, national and international affairs ... Many people are still living, and a mishandling of the situation can become a political problem ... No one is quite sure how to do it properly." $" 63$

Zhou Enlai's inspection of the exhibition on 20 September 1959 raised a thorny question. As the Premier was about to depart, Wang Yeqiu asked for his reaction. Zhou, recalled one young museum staff member who was present, made one succinct comment: "Not enough prominence is given to the Red Line (hongxian) after the May Fourth Movement." 64 But what exactly was the Red Line? In the expanded 159th meeting of the CCP Secretariat two days later, which Wang Yeqiu was asked to attend, Zhou explicitly outlined his meaning. "In the exhibition of the New Democratic Revolution," he stated, "the Red Line of Mao Zedong Thought was inconspicuously displayed." And he continued: "The Red Line is the fundamental and most critical issue, and we must use it to unite different parties and to mobilize our actions." ${ }^{65}$ The meeting concluded with a clear directive: "The exhibitions in the two museums [the Museum of the Chinese Revolution and the Military Museum] must show that politics is in command, using Chairman Mao's correct thought and revolutionary line as the guiding principle." 66 Since the exhibition in the Museum of the Chinese Revolution had failed to meet this goal, the official opening was postponed until revisions were satisfactorily accomplished.

60. Ibid. p. 7.

61. Mao Zedong, "On new democracy," in Mao, Selected Works, Vol. 2, pp. 339-384.

62. Hu Qiaomu, Zhongguo gongchandang de sanshinian (Thirty Years of the Communist Party of China) (Beijing: Renmin chubanshe, 1951).

63. Yu Jian, "Inspecting the exhibitions," pp. 267-268.

64. Ibid. p. 272.

65. Ibid. p. 273.

66. The Yearbook of Beijing Museums, p. 199. 
On 8 October 1959, the Ministry of Culture, led by Qian Junrui, proposed the following principles as a guide for future revisions: "Underscore the Red Line, omit no major historical events, shorten the battle line and enhance the aura." ${ }^{\circ 7}$ It was evident by now to many senior officials that reaching a consensus on an exhibit of the New Democratic Revolution would be difficult, at best, and that therefore they should refrain from even attempting to tackle the third and even more controversial socialist period. Indeed, in 1960, the CCP Central Committee ordered the museum to "temporarily shelve the socialist period." 68

Thus the central issue remained the question of how the Red Line could be properly delineated. The museum staff made another attempt to revise the exhibit in 1960. This time, however, they seemed to have gone too far. To Zhou Yang's chagrin, artifacts associated with Mao now appeared in great abundance. The Chairman's photos and quotations (yulu), for example, were everywhere. Moreover, instead of Mao's original publications, such as his "Report on an investigation of the peasant movement in Hunan," replicas were used. They were also doubled in size from the original scheme of one-sixteenth of a sheet of paper to oneeighth. ${ }^{69}$ Zhou Yang, on revisiting the museum in February 1961, underscored the importance of presenting the audience with genuine objects, and he charged that the presentation of Mao's publications was excessive. "The result," he said, "was that it was not the 'Red Line' that was being displayed in the museum but rather the 'Red Silk'."70 Kang Sheng disagreed, however, contending that Mao's items were not overly prominent and arguing that it was necessary that Mao's pre-eminence be singularly demonstrated. To him, displaying the artifacts of many other leaders was tantamount to others "making rival claims as an equal" (fenting kangli) to the Chairman which, Kang insisted, was a bad idea. ${ }^{71}$ Unfortunately no archival records exist to show how this conflict was ultimately resolved. We do know, however, that when Deng Xiaoping came to inspect the exhibition on 16 May before the museum's official opening one-and-half months later, his opinion reflected the broader view of Zhou Yang. Noticing that only one picture of Li Dazhao was on display, Deng objected, saying, "Li was a founding member of the Party, and to have just one picture of him is totally unacceptable.",72

\section{The Opening Exhibition}

Objects and specimens in a museum, Susan Pearce maintains, are "at the heart of the museum operation." ${ }^{, 3}$ Exactly what were the items

67. Fan Kongmu, "The history of the development of the exhibitions," p. 6.

68. Ibid. pp. 6-7.

69. Interview with museum staffer A, January 2005.

70. Yu Jian, "Zhou Yang and museums."

71. Fang Kongmu, "Tan dangshi gongzuo zhong de jige wenti” ("On several issues related to the research on Party history"), Dangshi yanjiu ziliao (Research Materials on Party History) (Chengdu: Sichuan renmin chubanshe, 1980), p. 477.

72. Fan Kongmu, "The history of the development of the exhibitions," p. 7.

73. Susan M. Pearce, Museums, Objects and Collections: A Cultural Study (Washington, DC: Smithsonian Institution Press, 1993), p. x. 
exhibited in the grand opening of the Museum of the Chinese Revolution on 1 July 1961, the 40th anniversary of the founding of the CCP? Unfortunately the archives of the museum remain closed to outsiders, and a full inventory of the displayed artifacts is currently unavailable. However, photographs, articles and newspaper reports of the exhibition do exist. The following is a partial reconstruction of the exhibition based on these materials and on memoirs and interviews. ${ }^{74}$

At its commencement the museum included displays on only two periods, the Old and the New Democratic Revolutions, eliminating the socialist era. The first period, from the Opium War to the 1911 Revolution, was characterized by what Mao described as a series of fierce struggles against foreign aggression abroad and feudal forces at home. A primary display was a huge cannon guarding the Bogue near the southern city of Guangzhou, defending the nation against British naval attacks in the Opium War. Also on display was Commissioner Lin Zexu's famous memorial to Emperor Daoguang about the dangers of the opium trade and his determination to stop drug trafficking. The Taiping Rebellion occupied an equally prominent place, with Hong Xiuquan's imperial seal and the anti-Manchu declarations by the Taiping rebels on view, demonstrating the importance of this controversial episode in communist historiography. In another hall of the museum, one could view the swords and spears used by the Boxers to battle the Allied forces during the Boxer Uprising in 1900. Details of the 1911 Revolution were also exhibited.

The museum's emphasis, however, was unquestionably on the New Democratic Revolution. Of the 4,152 square metres devoted to the exhibition, three-quarters, about 3,000 square metres, was allotted to this second period; and of the 3,600 items exhibited, the majority also belonged to this second period. ${ }^{75}$ Predictably the central focus was on the inevitable rise of the CCP in China. A huge bust of Mao Zedong graced the entrance hall leading to the exhibition on this period. The first artifacts on display centred on the introduction of Marxism to China from the Soviet Union. Mao Zedong's famous saying, "The salvoes of the October Revolution brought us Marxism-Leninism" (1949), ${ }^{76}$ was placed above a model of the cruiser Aurora along with one of its shells, a gift from the Soviet Union, that had been used in an attack on the Winter Palace in 1917. A replica of Vladimir Serov's oil painting Lenin Declares Soviet Power (1947) hung on another wall. An original copy of the Chinese translation of The Communist Manifesto, published in Shanghai in 1920 , was also on view. ${ }^{77}$

74. The primary sources are: photo illustrations from Wenwu, No. 7 (July 1961); Benkan jizhe [Wang Yeqiu], "Zhongguo gemin bowuguan xunli" ("A tour of the Revolutionary Museum”), Wenwu, No. 7 (July 1961), pp. 27-37; Zhongguo geming bowuguan fazhan jishi, Illustration 37; Geming bowuguan gongzuo yanjiu, No. 3 (1984), p. 3, and illustrations. Interviews with museum staffers A, B, C and D.

75. Renmin ribao, 1 July 1961; interview with museum staffer A.

76. Mao Zedong, "On the people's democratic dictatorship," in Mao, Selected Works, Vol. 4, p. 413.

77. Wenwu, No. 7 (July 1961). 
But items regarding the early Soviet influence on China formed merely a prelude to the more important subject, the founding of the CCP in China, and thereafter the Soviet element of the exhibition diminished drastically. A replica of the site of the First Party Congress was on display. But the emphasis was on the leading role played by Mao Zedong. Occupying the centre of the hall were five huge photographs of the participants in the First Party Congress: Mao Zedong in the middle, flanked on his left by Dong Biwu and Chen Tanqiu (1896-1943) and on his right by He Shuheng (1876-1935) and Wang Jinmei (1898-1925). Above these hung another of Mao's famous sayings: "In China, the Communist Party was born, an epoch-making event" (1949) ${ }^{78}$ The key position of Mao's portrait and his authoritative saying served to reinforce his centrality in Party history dating back to the beginning of the communist movement in China.

Li Dazhao was given more prominent treatment than he had received in the preliminary exhibitions, where only one photograph of him was on display. Now, not only were his influential writings being shown, including "The victory of the masses," but his pictures also occupied a more elevated place in the communist pantheon of heroes. While the exhibition clearly followed a Marxist script by underlining the importance of the proletariat in the Chinese revolution, displaying weapons such as axes and knives used by workers during urban uprisings (as in the Shanghai strikes in 1926 and 1927), equal weight was devoted to the rising peasant movement in rural China. Visitors could view an original copy of Mao Zedong's "Report on an investigation of the peasant movement in Hunan," printed in Hankou in April 1927, as well as makeshift flags used by peasant associations to rally support in their attacks against local tyrants and evil gentry.

The artifacts from the Second Revolutionary Civil War were clearly militaristic in nature, beginning with a display illustrating the birth of the Red Army in the Nanchang Uprising in August 1927. Not unexpectedly, the legendary Long March was given detailed and heroic treatment, with a soldier's straw sandal displayed to demonstrate the hardship the troops endured during the ordeal. ${ }^{79}$ A model of Zunyi Conference Hall, where Mao assumed the top posts in the Party in 1935, was placed in the middle of the hall to signify the beginning of a new era of correct leadership in the CCP.

The hall chronicling the War of Resistance illustrated the Communists' activities on two fronts: resisting the Japanese invasion and building a socialist base in Yan'an. Armbands of the Eighth and New Fourth Armies were displayed, as was the weaponry captured during the victorious battle against the Japanese troops at Pingxing Pass in north-east Shanxi in September 1937. The specific mention of the campaign, led by forces commanded by Lin Biao (who had replaced Marshal Peng Dehuai

78. Mao Zedong, "The bankruptcy of the idealist conception of history," in Mao, Selected Works, Vol. 4, p. 456.

79. Renmin ribao, 15 February 1962. 
(1898-1974) as China's minister of defence after the Lushan Conference in 1959), was an obvious indication of Lin's rising influence. But the Rectification Campaign in Yan'an was given even more conspicuous treatment. On the wall, for example, was Luo Gongliu's oil painting The Rectification Report, which shows Mao in a simple hall, his left hand raised in the air, standing before portraits of Marx and Lenin, passionately delivering his famous speech to a rapt audience. ${ }^{80}$

On display in the final episodic theme, the Third Revolutionary Civil War, were details, including maps and weaponry, of the three military campaigns launched by the Communists during the civil war against the Nationalists, in Manchuria, north China and central China. In an exhibition of the Second Plenum of the Seventh Central Committee of the CCP, held in March 1949, Mao is seen laying down the foundation for a future socialist China by convening the Political Consultative Conference and forming a future "democratic coalition government." The room adjacent to this display showed the triumphant conclusion of the Communists' victory in the civil war and the founding of the PRC. Dong Xiwen's Founding of the Nation, gracing a huge wall, symbolizes the historic moment.

\section{Conclusion}

After its inauguration in 1961, the Museum of the Chinese Revolution would undergo several transformations. During the Cultural Revolution, in November 1966, radicals closed down the museum. It was reopened in 1969 but this time merged with the Historical Museum to form the Chinese Revolutionary Historical Museum. Fourteen years later, in 1983, the museum reclaimed its original name. ${ }^{81}$ Recently, in February 2003, yet another incarnation took place: the government ordered that the museum merge once again with the Historical Museum, forming a new Chinese National Museum (Zhongguo guojia bowuguan), placed under the supervision of the Ministry of Culture. This new museum is scheduled to open its doors in 2007, in time for the 2008 Beijing Olympics. It is likely that this will not be the end of the story of this controversial political institution.

The Museum of the Chinese Revolution was a political arena where the Chinese Communists narrated and presented their own story. Although portraits and paintings of Marx and Lenin were displayed in the spirit of communist internationalism, the museum's focus was unmistakably domestic. The aim was primarily to tell a carefully scripted tale of the inevitable rise of the $\mathrm{CCP}$, led by Mao Zedong, as he directed the populace in a fight against the oppressive Kuomintang at home and the callous imperialists abroad (particularly the Japanese and the Americans), ultimately liberating his people. "In essence," one museum

80. Interview with Luo Gongliu.

81. The 50 Years of the Museum of the Chinese Revolution, pp. 143, 148-49. 
worker reminded me, "the entire modern Chinese history should be read as a history led by the CCP." 82

The formative period of the museum in the late 1950s must be examined within the larger context of Chinese politics and international relations during this time, an era characterized by a growing rift between China and the Soviet Union and marked by the tumultuous Great Leap Forward initiated by Mao, which stretched from late 1957 to the early 1960s. Of course, from 1959 to 1961, China also suffered from severe natural calamities - extensive floods and droughts - and, moreover, with the fiasco of the Great Leap Forward, China was retreating from the radical stance of Maoism. Nevertheless Mao's position in the Party remained unchallenged. In fact, the ousting of Peng Dehuai after the Lushan Conference rekindled Mao's conviction in his revolutionary vision. The publication of the fourth volume of his Selected Works in October 1960 may be seen as Mao's way of reaffirming his supreme position in the Party. Indeed, Mao did make a form of self-criticism concerning the Leap at a Party Central Work Conference in Beijing in June 1961. But, as Kenneth Lieberthal points out, this criticism was "never circulated to lower levels of the Party," and the Chairman's "own responsibility was carefully shielded to protect his legitimacy." ${ }^{33}$ Many museum staff members whom I interviewed in China reiterated a similar view: that the Lushan Conference might have tarnished Mao's prestige at a later date, when details became more publicly known, but at the time it actually further consolidated his personal dominance in the Party. ${ }^{84}$ Mao's unparalleled position remained relatively intact after the Great Leap. A principal reason may be that, as Roderick MacFarquhar suggests, "the men who could have made political capital about the failure of the leap - Chou En-lai [Zhou Enlai], Ch'en Yun [Chen Yun], Li Fu-ch'un [Li Fuchun] - had never shown any disposition to challenge his personal position or authority." 85

Did the 1961 exhibition reflect the shifting political tide at that time? Soviet influence was certainly played down. Peng Dehuai's pictures were removed from the 1961 exhibition. ${ }^{86}$ But Lin Biao's achievements, especially his Pingxing Pass victory against the Japanese in 1937, were highlighted and hence glorified. Was Mao's Red Line too excessively presented in the opening exhibition, as Zhou Yang once criticized? Because no information is available on the details of the prior trial exhibitions (inventories and catalogues), we do not know for certain. But judging from the items being shown in the 1961 exhibition, Mao's Red Line was systematically and prominently displayed. While it is true that

82. Interview with museum staffer A.

83. Kenneth Lieberthal, "The Great Leap Forward and the split in the Yenan leadership," in Roderick MacFarquhar and John K. Fairbank (eds.), The Cambridge History of China, Vol. 14 (Cambridge: Cambridge University Press, 1987), p. 321.

84. Interviews with museum staffers A, B, C and D.

85. Roderick MacFarquhar, The Origins of the Cultural Revolution, 2: The Great Leap Forward 1958-1960 (New York: Columbia University Press, 1983), p. 336.

86. Interview with museum staffer D. 
other senior leaders such as Liu Shaoqi (in his role as organizer of the Anyuan workers) and Zhou Enlai (for his part in the Nanchang Uprising) were duly mentioned, Mao unquestionably took centre stage, even as he was being lionized in the larger social and political context of modern Chinese history. This broader context had been recommended by Zhou Yang.

Duncan and Wallach, in their study of "universal survey museums" the Louvre in Paris and the Metropolitan Museum of Art in New York argue that the architecture, layout of rooms and sequence of collections of these museums create "an experience that resembles traditional religious experiences." In walking through the museum, the visitor "moves through a programmed experience that casts him in the role of an ideal citizen," thus affirming and legitimizing the concept of the modern state. ${ }^{87}$ Although the Museum of the Chinese Revolution succeeds in producing such an experience, it was built to serve a very different purpose. The successive historical periods, Chairman Mao's sacred texts and the carefully selected battle scenes all form a coherent iconographic programme to be imparted to museum visitors. And the Party, reflecting its exclusive and monopolistic nature, controlled the means of representing the past. The museum space was never intended to reveal history in all its diversity, complexity and contradiction. Instead, its orientation was towards a singular interpretation in line with the political reality in China.

87. Duncan and Wallach, "The universal survey museum," pp. 450-51. 